\title{
The Mediterranean diet: Effects on proteins that mediate fatty acid metabolism in the colon
}

Zora Djuric

\begin{abstract}
A Mediterranean diet appears to have health benefits in many domains of human health, mediated perhaps by its anti-inflammatory effects. Metabolism of fatty acids and subsequent eicosanoid production is a key mechanism by which a Mediterranean diet can exert anti-inflammatory effects. Both dietary fatty acids and fatty acid metabolism determine fatty acid availability for cyclooxygenase- and lipoxygenase-dependent production of eicosanoids, namely prostaglandins and leukotrienes. In dietary intervention studies and in observational studies of the Mediterranean diet, blood levels of fatty acids do reflect dietary intakes but are attenuated. Small differences in fatty acid levels, however, appear to be important, especially when exposures occur over long periods of time. This review summarizes how fat intakes from a Greek-style Mediterranean diet can be expected to affect fatty acid metabolizing proteins, with an emphasis on the metabolic pathways that lead to the formation of proinflammatory eicosanoids. The proteins involved in these pathways are ripe for investigation using proteomic approaches and may be targets for colon cancer prevention.

๑) 2011 International Life Sciences Institute
\end{abstract}

\section{INTRODUCTION}

There is substantial epidemiological evidence that indicates dietary patterns influence colorectal cancer risk. ${ }^{1-3}$ One such dietary pattern that holds great promise for cancer prevention is the Mediterranean dietary pattern, which is based on the Greek diet consumed in Crete. All of the major components of the traditional Cretan diet, namely olive oil, fish, cereals, legumes, fruits, and vegetables, have been associated with decreased colorectal cancer risk. ${ }^{4-10}$ Relative to the American diet, this diet results in lower intake of n-6 versus n-3 and n-9 fatty acids, lower intake of polyunsaturated fatty acids (PUFAs), lower intake of red meat, and much higher intake of plant-based foods and monounsaturated fatty acids (MUFAs). ${ }^{11-14}$

In intervention studies and in observational studies of the Mediterranean diet, blood levels of fatty acids do reflect dietary intakes, but the differences in blood levels among populations are much smaller than the differences in dietary intakes (Table 1). It is, therefore, very important to consider the absorption, distribution, and metabolism of fatty acids since these factors will limit changes in blood and tissues when the diet is changed. Small differences in fatty acids may, nonetheless, be important, especially when exposures occur over longer periods of time, and may be responsible for the preventive effects of a Mediterranean diet against colon cancer. This review evaluates the potential impact of this type of eating pattern on fatty acid metabolic pathways. Fatty acid metabolism regulates the amount of arachidonic acid that is available in cell membranes for subsequent formation of proinflammatory eicosanoids. Eicosanoids, particularly prostaglandin $\mathrm{E}_{2}$ (PGE2), have been shown to be key mediators of colonic carcinogenesis. ${ }^{15}$

Affiliation: Z Djuric is with the Departments of Family Medicine and Environmental Health Sciences (Nutrition Program), University of Michigan, Ann Arbor, Michigan, USA.

Correspondence: Z Djuric, University of Michigan, 1500 E. Hospital Drive, Room 2150 Cancer Center, Ann Arbor, MI 48109-5930, USA. E-mail: zoralong@umich.edu. Phone: +1-734-615-6210, Fax: +1-734-647-9817.

Key words: dietary intervention, fatty acids, inflammation, Mediterranean diet, proteomics 
Table 1 Dietary intakes and changes in levels of fatty acids in blood in select Mediterranean dietary interventions that successfully increased monounsaturated fatty acid (MUFA) intakes and reported levels of fatty acids in blood. The "Change" columns show either the change from baseline or differences versus a control group, depending on how it was reported in each publication. The dietary fat intakes used for the calculation were expressed as percentage of energy intake.

\begin{tabular}{|c|c|c|c|}
\hline Study & Intervention & Change in diet & $\begin{array}{l}\text { Change in blood } \\
\text { fatty acids }\end{array}$ \\
\hline $\begin{array}{l}\text { de Lorgeril et al. (1998)* Lyon Diet } \\
\text { Heart Study }{ }^{169}\end{array}$ & $\begin{array}{l}\text { Provided counseling and a } \\
\text { high-MUFA spread }\end{array}$ & 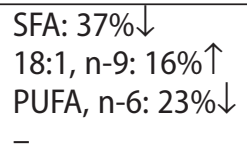 & $\begin{array}{l}\text { SFA: } 2 \% \downarrow \\
\text { 18:1, n-9: } 12 \% \uparrow \\
\text { PUFA, n-6: } 8 \% \downarrow \\
\text { PUFA, n-3: } 12 \% \uparrow\end{array}$ \\
\hline $\begin{array}{l}\text { Djuric et al. }{ }^{173,174}(2009)^{\dagger} \\
\quad \text { Mediterranean Eating Study }{ }^{173,174}\end{array}$ & Provided exchange-list counseling & $\begin{array}{l}\text { SFA: } 21 \% \downarrow \\
\text { MUFA: } 59 \% \uparrow \\
\text { PUFA: } 21 \downarrow\end{array}$ & $\begin{array}{l}\text { SFA: } 5 \% \downarrow \\
\text { MUFA: } 25 \% \uparrow \\
\text { PUFA: } 1 \% \downarrow\end{array}$ \\
\hline Paniagua et al. $(2007)^{\ddagger}, 167$ & Provided all food & $\begin{array}{l}\text { SFA: } 61 \% \downarrow \\
\text { MUFA: } 156 \% \uparrow \\
\text { PUFA: } 0 \downarrow\end{array}$ & 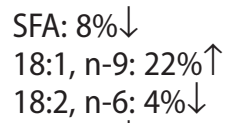 \\
\hline Urquiaga et al. $(2004)^{\S}$, & Provided all food & $\begin{array}{l}\text { SFA: } 37 \% \downarrow \\
\text { MUFA: } 7 \% \uparrow \\
\text { PUFA: } 2 \downarrow\end{array}$ & $\begin{array}{l}\text { SFA: } 4 \% \downarrow \\
\text { MUFA: } 11 \% \uparrow \\
\text { PUFA: } 7 \downarrow\end{array}$ \\
\hline Vessby et al. (2001)ף KANWU study ${ }^{168}$ & $\begin{array}{l}\text { Provided fats as well as counseling } \\
\text { about high-MUFA diet }\end{array}$ & $\begin{array}{l}\text { SFA: } 28 \% \downarrow \\
\text { MUFA: } 62 \% \uparrow \\
\text { PUFA: } 2 \downarrow\end{array}$ & $\begin{array}{l}\text { SFA: } 2 \% \downarrow \\
\text { 18:1, n-9: } 10 \% \uparrow \\
\text { 18:2, n-6: } 9 \% \downarrow\end{array}$ \\
\hline $\begin{array}{l}\text { Vincent-Baudry et al. }(2005)^{* *} \\
\text { Medi-RIVAGE Study }{ }^{175}\end{array}$ & Provided counseling & $\begin{array}{l}\text { SFA: } 31 \% \downarrow \\
\text { MUFA: } 9 \% \uparrow \\
\text { PUFA: } 7 \uparrow\end{array}$ & $\begin{array}{l}16: 0: 6 \% \downarrow \\
18: 1, n-9: 3 \% \uparrow \\
18: 2, n-6: 1 \% \downarrow\end{array}$ \\
\hline $\begin{array}{l}\text { Zazpe et al. }(2008)^{\dagger \dagger} \text { PREDIMED } \\
\text { Study }{ }^{201}\end{array}$ & Provided counseling & $\begin{array}{l}\text { SFA: } 5 \% \downarrow \\
\text { MUFA: } 11 \% \uparrow \\
\text { PUFA: } 3 \uparrow\end{array}$ & $\begin{array}{l}- \\
18: 1, n-9: 2 \% \uparrow\end{array}$ \\
\hline
\end{tabular}

* For the study of de Lorgeril et al., data from individuals without cancer was used, and the difference between the intervention group and the control group is shown. Dietary intakes of n-3 PUFA were not given. Fatty acids were measured in plasma 2 months after randomization.

${ }^{\dagger}$ Data are for the decrease over 6 months in the intervention arm (percent change from baseline). Fatty acid levels were those measured in total fasting plasma phospholipids.

${ }^{\ddagger}$ Differences between a high-MUFA diet and an SFA diet are shown after 28 days. Fatty acid levels were those measured in plasma phospholipids.

${ }^{\S}$ Differences are shown between a Mediterranean diet ( $27 \%$ of energy from fat) and an Occidental diet ( $40 \%$ of energy from fat) after 30 days of feeding. Fatty acids were measured in total plasma.

" Change is from baseline to mean over 90 days of treatment. Fatty acid analysis was of serum phospholipids.

** Data are for change from baseline to 3 months in the Mediterranean intervention group. Fatty acids were those measured in fasting plasma.

${ }^{\mathrm{t}}$ Data are for change from baseline over 12 months in the Mediterranean plus olive oil group. Fatty acids were those measured in fasting plasma.

Only oleic acid and linolenic acid levels were reported in blood.

Abbreviations: MUFA, monounsaturated fatty acids; PUFA, polyunsaturated fatty acids; SFA, saturated fatty acids.

\section{MEDITERRANEAN DIET AND COLON CANCER RISK}

Every person in the industrialized world has, on average, a 1 in 20 chance of developing colorectal cancer in his or her lifetime, and rates in the United States are the highest (55 cases/100,000 population in 2000). ${ }^{1,16,17}$ Dietary practices have been implicated in the risk of colorectal cancer, although dietary effects per se may be difficult to disentangle from obesity effects. Risk is typically lower in population groups that do not follow the typical American diet, and risk has been shown to increase in migrants who move to the United States. ${ }^{17}$ In Greece, rates of colorectal cancer are very low, but they are elevated in Greeks who have moved to Australia. ${ }^{18-20}$ Rates of colorectal cancer mortality in Greece in 1955 were 5-8/100,000 population and have increased to about $10 / 100,000$ in 2000 , perhaps as diets have drifted away from the traditional patterns. ${ }^{21}$

Case-control studies of colorectal cancer risk and diet have fairly consistently found that intakes of fruit, vegetables, fish, and whole grains are protective, while red meat and refined carbohydrates are associated with increased risk. ${ }^{4,5}$ In the Breast Cancer Demonstration Project, increased compliance with a Recommended Food Score was associated with a 51\% reduction in colorectal cancer risk. ${ }^{22}$ However, increased fruit and vegetable consumption alone, from a pooled analysis of 14 
studies, reduced only distal colon cancer risk..$^{23}$ Eating patterns may, therefore, play a more important role in colon cancer risk reduction than consumption of any specific food or nutrient, and this may be the ideal approach for prevention. ${ }^{24-27}$

A complex mixture of protective compounds can only be obtained from a dietary pattern-based approach, and methods have been developed to score adherence to a Mediterranean-style diet. In persons who followed a Mediterranean eating pattern, recurrence of adenomatous polyps was decreased, with an odds ratio of 0.3 for the third versus the first tertile. ${ }^{8}$ In one large Greek study, a Mediterranean diet score was constructed to reflect the traditional Mediterranean diet. Higher scores were significantly associated with decreased mortality from all cancers $(24 \%$ reduction in mortality for every 2 -point increase in the score), but generally, intakes of specific foods were either not associated with mortality or the association was much weaker. ${ }^{28}$ Note that in studies done in the United States, the extent of Mediterranean-style eating, as defined by being above/below median values, will differ from that in European studies due to differences in the median intakes of foods. In two recent US studies, a Mediterranean dietary pattern had a significant protective effect against colon cancer in men only. ${ }^{29,30} \mathrm{In}$ the American Association of Retired Persons cohort, however, total cancer mortality in both men and women decreased significantly along with increased adherence to a Mediterranean dietary score. ${ }^{31}$

\section{MECHANISMS BY WHICH FATTY ACIDS CAN AFFECT COLON CANCER RISK}

A unique aspect of the Mediterranean diet is the different type of fat that is ingested. Increasing fiber alone does not appear to be sufficient to significantly impact the risk of colon cancer, and increased intakes of fruit and vegetables has been shown to have modest effects. ${ }^{23,32-34}$ Fatty acids are substrates for eicosanoid production, and eicosanoids can activate proinflammatory pathways that promote colon carcinogenesis. PGE2, formed from arachidonic acid by constitutive cyclooxygenase 1 (COX-1) and inducible cyclooxygenase 2 (COX-2) in the colonic mucosa, plays an important role in the expansion of cell populations in the colonic crypt and subsequent formation of adenoma. ${ }^{35-39}$ Cyclooxygenase (COX) inhibitors conversely block proliferation, induce apoptosis, and inhibit angiogenesis in the colon..$^{40}$ Inhibition of both COX-1 and COX-2 appears to be effective for preventing polyp formation and greatly reduces colon cancer risk. ${ }^{41,42}$ It appears that reducing the level of PGE2 levels in normal tissue could lead to a reduced risk of polyp formation, and PGE2 has been identified as an appropriate prevention endpoint. ${ }^{43-45}$
There are several examples of eicosanoid modulation by dietary fats. The colon-tumor-promoting effects of corn oil, which is very high in linoleic acid $(18: 2, n-6)$, have been related to COX-2 induction, while diets rich in high-fat fish oil have been found to decrease COX-2 protein expression. ${ }^{46}$ Intervention with a Mediterranean dietary pattern does not greatly increase n-3 fatty acid intakes in the manner that fish oil supplementation would, but n-6 fatty acid intakes are decreased by $30 \%$ or more to help shift the $n-3: n-6$ ratio, which greatly impacts the formation of PGE2 and leukotrienes. ${ }^{47,48}$ In rats, the n-3:n-6 dietary ratio was found to be more important than the total amount of n-3 fatty acid intake in inhibiting 12-hydroxyeicosatetraenoic acid (12HETE), 6-keto-prostaglandin F2 $\alpha$, and thromboxane B2. ${ }^{49}$ The role of $\mathrm{n}-9$ fatty acids, such as oleic acid (18:1) found in olive oil, has not been studied as extensively, but Bartoli et al. ${ }^{50}$ observed inhibition of aberrant crypt foci and adenocarcinomas, decreased mucosal arachidonate (20:4), and decreased PGE2 in rats fed either n-9 or $n-3$ diets relative to rats fed diets high in $n-6$ fatty acids.

\section{COLONIC PROTEOME AS A MEDIATOR OF DIETARY EFFECTS ON MUCOSAL FATTY ACIDS AND EICOSANOIDS}

Dietary fatty acids can impact both the types and the levels of eicosanoids produced in the colonic mucosa. The proteins of interest that can mediate the effects of dietary fatty acids on colonic fatty acid and eicosanoid levels are depicted in Figure 1. These have been selected for this review based on their possible contribution to altering fatty acid ratios in cells, and many have been shown to be relevant to changes during colon carcinogenesis as well. The link between diet and eicosanoid production has barely been studied, yet the impact of metabolism on limiting changes in membrane fatty acids and, subsequently, eicosanoids is important for determining colon cancer risk.

\section{Fatty acid-binding proteins}

Role in fatty acid metabolism. There are a number of proteins involved in binding fatty acids for the purpose of transport between and within cells. Among them, perhaps the best-described are the fatty-acid-binding proteins (FABPs). These proteins are abundant in the cytosol of cells, can bind many hydrophobic ligands, and are induced by increased levels of fatty acids. FABPs bind fatty acids and fatty acyl coenzyme A (CoA) with high affinity in the cytoplasm and then translocate to the nucleus. The nuclear receptors for liver FABPs appear to 


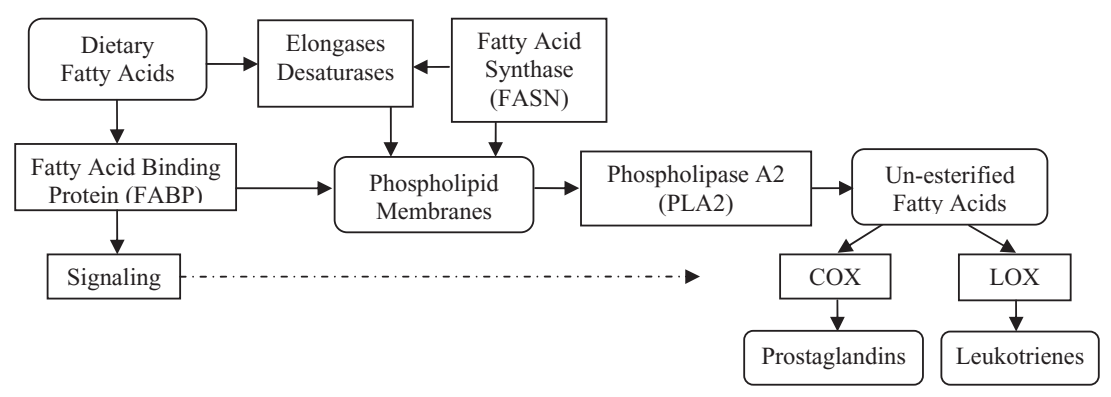

Figure 1 Metabolism of dietary fatty acids to eicosanoids. Metabolic processes modulate the effect of dietary changes on fatty acid levels in membranes and on the eicosanoids that are formed.

be peroxisome proliferator-activated receptors (PPARs) alpha and gamma, which in turn regulate production of FABPs and other genes needed for nutrient metabolism. ${ }^{51}$

FABPs from the same tissues across species have similarities in fatty acid binding affinity, while there is wide variation in the affinity of FABPs from different tissues. ${ }^{52}$ Two forms of FABPs have commonly been identified in the human colon, namely liver FABP (L-FABP) and intestinal FABP (I-FABP), with levels of L-FABP being higher. ${ }^{53-55}$ In a proteomic study, I-FABP was a major protein identified in human intestinal scrapings from both the small and large intestine using twodimensional gel electrophoresis, although the I-FABP level was twofold higher in the small versus the large intestine. $^{56}$

I-FABP appears to be involved in absorption of fatty acids from the intestinal lumen and synthesis of triglycerides, while the role of L-FABP may be related more to the uptake of fatty acids from the plasma for energy production and phospholipid synthesis. ${ }^{57}$ The mechanism of fatty acid movement has been investigated with a model fatty acid, and it was shown that transfer of fatty acids to L-FABP and I-FABP occurs via different mechanisms, with I-FABP having a bigger role in the transfer of fatty acids between membranes and sites of metabolism and L-FABP having the ability to buffer high levels of fatty acids in enterocytes. ${ }^{58}$ The I-FABP in humans has a higher affinity for PUFAs than for oleic acid or saturated fatty acids..$^{52}$

Role in colon cancer risk. Both I-FABPs and L-FABPs have been shown to be decreased in colon carcinoma. ${ }^{59}$ Conversely, increased expression of L-FABP in colorectal cancer and metastatic foci was associated with increased survival, pointing to the protective role of L-FABP. ${ }^{60}$ L-FABP contains a PPAR response element and can bind two ligands simultaneously, unlike other FABPs, and activation of PPAR gamma can protect the colon against colitis. $^{61,62}$

In addition to binding fatty acids, FABPs appear to mediate the signaling associated with fatty-acid-induced inflammation in cells. ${ }^{53}$ Several FABPs have been shown to stabilize leukotriene A4 in cells, which could then have an impact on inflammatory states and hence colon cancer risk. ${ }^{63}$ Work in transgenic mice indicated that deletion of adipocyte FABP did not alter phenotype greatly, but the response to inflammatory stimuli was hampered. ${ }^{64}$ Interestingly, levels of epidermal FABP in skin were 50\% lower in transgenic mice that overexpress COX-2, an enzyme known to increase during colonic inflammation and tumorigenesis. ${ }^{65}$

\section{Effect of diet}

The effect of a high-fiber wheat-bran diet that decreased colonic tumors in rats resulted in increased L-FABP and I-FABP in exfoliated colon cells, which would be consistent with a protective effect of FABPs. ${ }^{66}$ Soy or whey protein diets, however, decreased colonic I-FABP in carcinogen-treated rats. ${ }^{67}$ Oleic acid, a main component of olive oil, which is one of the staples of Mediterranean diets, increased L-FABP and I-FABP in the small intestine, but linoleic acid was even more stimulatory in rodent models. ${ }^{68-70}$ The effects of a Mediterranean diet on FABPs are therefore difficult to predict.

The effects of diet on FABPs may also be affected by genotype. In humans, a fairly prevalent polymorphism in I-FABP (Ala54Thr) was shown to be important in mediating the effects of diet on insulin resistance. Carriers of the Thr54 allele had higher glucose levels than individuals with the Ala54/Ala54 homozygote, but only the Thr54 carriers displayed decreases in glucose levels with a low-fat or Mediterranean diet.. ${ }^{71}$ Thr54 carriers also maintained better insulin sensitivity when consuming olive oil diets versus sunflower oil diets, while the type of fat intake did not affect those with the Ala54a/ Ala54 homozygote. ${ }^{72}$ In obese children who were carriers of the Thr54 allele, activation of delta- 6 fatty acid desaturase was impaired in response to low levels of arachidonic acids, indicating the inter-relationships of these pathways. ${ }^{73}$ 


\section{Fatty acid synthase}

Role in fatty acid metabolism. De novo synthesis of nonessential fatty acids can markedly contribute to tissue levels. Fatty acid synthase (FASN) is a $250-\mathrm{kDa}$ protein responsible for the de novo synthesis of long-chain fatty acids, which are stored as triglycerides and used as a source of energy when needed. ${ }^{74}$

Role in colon cancer risk. FASN is expressed in normal human colon at the base of the crypts and is greatly overexpressed in colon tumors. ${ }^{75,76}$ Overexpression of FASN was associated with worse colon cancer survival rates in overweight and obese (but not normal-weight) individuals. ${ }^{77}$ In fact, inhibition of FASN has been suggested to be a viable therapeutic option for diabetes and cancer. ${ }^{78}$ Inhibition of FASN has been suggested to be a target for cancer prevention. ${ }^{79}$ Several dietary chemopreventives (soy, epigallocatechin gallate, and acer) have been shown to inhibit FASN. ${ }^{80-82}$

Effect of diet. Of importance to Mediterranean diets, oleic acid downregulates FASN protein expression in cultured tumor cells, which, in turn, downregulates expression of human epidermal growth factor receptor 2 (HER-2) ${ }^{83}$ In human colonic carcinoma cell line 2 (CaCo-2) cells, eicosapentaenoic acid (EPA, also known as 20:5, n-3) inhibited FASN much more strongly than did linoleic acid $(18: 2, n-6){ }^{84}$ In breast cancer cells that overexpress FASN, n-3 fatty acids and gamma-linolenic acid, but not other n-6 fatty acids, inhibited FASN activity and, possibly, expression. ${ }^{85}$ In glioma cells, oleic acid inhibited fatty acid synthesis. ${ }^{83,86}$ In vivo, a high-fat diet induced FASN, and FASN was overexpressed in a high proportion of aberrant crypt foci in human colon. ${ }^{87,88}$

Highly unsaturated fatty acids of 20-carbon length and greater are much more efficient than 18-carbon fatty acids in inhibiting FASN, but a caveat is that most studies have been done in experimental models using very high levels of fatty acids that do not mimic human exposures well. ${ }^{89}$ Experimental models, however, do suggest that increased intakes of olive oil might decrease protein levels of FASN. ${ }^{78}$ Both olive oil and fish oils, therefore, would be expected to decrease FASN expression.

\section{Desaturases and elongases}

Role in fatty acid metabolism. Stearoyl CoA desaturase (SCD-1) catalyzes the conversion of palmitate and stearate to their respective saturated fatty acids palmitoleate (16:1) and oleate (18:1), making it highly relevant to dietary interventions that are high in MUFAs. The other major desaturases are delta-5-desaturase (FADS1) and delta-6-desaturase (FADS2). FADS1 is involved in syn- thesis of 20:5, and FADS2 is the rate-limiting step in synthesis of both arachidonic acid (also known as 20:4, n-6) and EPA (20:5, n-3) from linoleic acid (18:2, n-6) and linolenic acid (18:3, n-3), respectively. Dietary intakes of arachidonic acid in humans are very low, about 110 $180 \mathrm{mg} /$ day for adults (of the $67-90 \mathrm{~g} /$ day total fat intake), yet this fatty acid compromises $5-10 \%$ of the phospholipid-derived fatty acids. ${ }^{90}$ This indicates that substantial conversion of linoleic acid (18:2, n-6) takes place to form arachidonic acid. Analogous pathways exist for the conversion of linolenic acid $(18: 3, n-3)$ to EPA $(20: 5, n-3)$, but the efficiency of this process is about $10 \%$ and it is inhibited by high intake of $n-6$ fatty acids. ${ }^{91,92}$

Desaturases and elongases (denoted Elovl for "elongation of very-long-chain fatty acids") are regulated in coordination with each other in the synthesis of longchain fatty acids. ${ }^{93}$ There are seven elongases that have been identified, none of which are specific to the colon, but Elovl 1, 5, and 6 are expressed in many tissues. Elovl5 is relevant to eicosanoid synthesis because it is involved in the conversion of 18:2 (n-6) to 20:4 (n-6) and 18:3 (n-3) to $20: 5(n-3) \cdot{ }^{94}$ In diabetes, increased retinal inflammation has been linked with decreased levels of $n-3$ fatty acids due to a decrease in expression of elongases. ${ }^{95}$

Role in colon cancer risk. Inhibition of FADS2 impeded intestinal tumorigenesis in Min mice. ${ }^{96}$ Fatty acid synthesis and lipid droplets, which store triglycerides, are increased in human colon cancer, implicating the importance of fatty acids in carcinogenesis. ${ }^{97}$

Effect of diet. A high-PUFA diet suppresses SCD-1, while a high-carbohydrate diet increases SCD- $1 .{ }^{98}$ The n-3 fatty acids are the preferred substrates for elongation and desaturation relative to $n-6$ fatty acids, but high $n-6: n-3$ ratios inhibit n-3 incorporation into membranes. ${ }^{99,100}$ With a Mediterranean diet, which is high in MUFAs, SCD-1 would likely be decreased when MUFAs are plentiful, while FADS2 may be increased to maintain arachidonate levels. With a low-PUFA diet, FADS2 expression was increased. ${ }^{101}$

Exercise and energy restriction have both been shown to enhance elongation of $\mathrm{n}-3$ fatty acids, resulting in increased levels of 20:5 (n-3) and 22:6 (n-3) in rodent skin without increased dietary intakes. ${ }^{102}$ When dietary n-3 fatty acids are increased using a fish-oil diet, expression of Elovl5 and desaturases is induced in rat liver relative to olive-oil diets. ${ }^{103}$ The changes observed with a Mediterranean diet will then depend on the levels of n-3 fatty acid intake. Elovl6, which is involved in the endogenous synthesis of MUFAs, ${ }^{93}$ will likely be decreased. Interestingly, Elovl6 knockout protected animals from insulin resistance induced by a high-PUFA diet. ${ }^{104}$ 


\section{Phospholipase $A_{2}$}

Role in fatty acid metabolism. Levels of free fatty acids are very low in cells, and most fatty acids are stored in phospholipids or triglycerides. Phospholipids in membranes appear to provide arachidonic acid ${ }^{173,174}(20: 4, n-6)$ for eicosanoid production, with triglycerides replenishing the phospholipid stores. ${ }^{97,105}$ Fatty acids are released from phospholipids by phospholipase $\mathrm{A}_{2}\left(\mathrm{PLA}_{2}\right)$ when needed for production of energy or to mount an inflammatory response. Upon stimulation of leukocytes, the enzymes involved in eicosanoid synthesis, including $\mathrm{PLA}_{2}$ and cyclooxygenases, act together in concert. ${ }^{106,107}$ Three $\mathrm{PLA}_{2}$ forms are thought to be primarily involved in arachidonate release upon stimulation: type IV cytoplasmic (c) $\mathrm{PLA}_{2 \alpha}$ and type IIA and type V secreted (s) $\mathrm{PLA}_{2}$ enzymes. ${ }^{108}$

Role in colon cancer risk. In human colon cancer, cPLA and sPLA type IIA are the most studied, but sPLA type $\mathrm{X}$ may also be important. ${ }^{109}$ Cytosolic $\mathrm{PLA}_{2}$ is generally regarded as the rate-limiting step in the release of fatty acids for eicosanoid production, and there are three isoforms, with cPLA ${ }_{2 \alpha}$ being prototypic. ${ }^{110,111}$ It is not known whether $\mathrm{CPLA}_{2 \alpha}$ could provide the bulk of arachidonate used in early or late prostaglandin synthesis or whether $\mathrm{CPLA}_{2}$ could simply act as a catalyst to stimulate secretion (or synthesis) of $\mathrm{SPLA}_{2} \mathrm{~s}$ necessary for early or late prostanoid synthesis. ${ }^{108}$ sPLA $_{2}$ may also function as a cytokine to help initiate and potentiate inflammation. ${ }^{112}$ In the colon, sPLA2 2 type IIA has been identified as a cancer susceptibility gene. ${ }^{113}$ However, it does appear that the secretory and cytoplasmic PLA $\mathrm{P}_{2}$ forms interact with each other to release arachidonic acid, making them all relevant in an examination of factors that can modulate inflammation. ${ }^{113}$ Data on the expression of $\mathrm{PLA}_{2}$ enzymes during carcinogenesis differs between mouse models and humans. In humans, both protein and mRNA of $\mathrm{sPLA}_{2}$ was elevated in five of six colorectal adenomas from persons with familial adenomatous polyposis, and this was associated with increased levels of arachidonic acid and COX-2 in the adenomas. ${ }^{114}$ Another group examined human colorectal carcinomas and found that a major percentage of samples strongly expressed $\mathrm{sPLA}_{2}$, but staining for ${ }^{c P L A} A_{2}$ was weaker. ${ }^{115} \mathrm{~A}$ similar scenario was found in Barrett's esophagus. ${ }^{116} \mathrm{~A}$ third study found no change in the expression of sPLA ${ }_{2}$ type IIA but increased expression of ${ }^{{ }^{2 P L A}}{ }_{2}$ and COX-2 in tumors. ${ }^{117}$ Consistent with this, a pro-apoptotic role has been proposed for $\mathrm{CPLA}_{2}{ }^{118}$ but not all studies have found lower $\mathrm{CPLA}_{2}$ in colon tumors versus normal tissue. ${ }^{109}$ Increased sPLA 2 type II activity in inflamed mucosa of patients with Crohn's disease and ulcerative colitis was attributed to increased protein levels, about threefold above that of healthy, control mucosa. ${ }^{119}$
In the rat model, $\mathrm{PLA}_{2}$ expression was higher in tumors than in normal colonic mucosa. ${ }^{120,121}$

Total $\mathrm{PLA}_{2}$ expression in human colon tissue was twofold higher in tumor tissue versus normal mucosa, ${ }^{122}$ and another study identified high levels of sPLA $\mathrm{A}_{2}$ type IIA in human colon cancer, especially in the periphery of the lesion. ${ }^{123}$ Thus, it appears that overexpression of $\mathrm{sPLA}_{2}$ plays a bigger role in colon tumors than $\mathrm{CPLA}_{2}$. In normal human mucosa, there is large variability in the expression of $s \mathrm{PLA}_{2}$ type IIA. ${ }^{124}$ One could speculate that variations in $\mathrm{PLA}_{2}$ levels in normal mucosa, with decreases in $\mathrm{CPLA}_{2 \alpha}$ and increases in $\mathrm{SPLA}_{2}$, could be related to increased cancer risk.

Effect of diet. In the rat model, expression of $\mathrm{PLA}_{2}$ in colonic mucosa was greater with a high-fat diet than with a low-fat diet. ${ }^{121}$ In humans, PLA $_{2}$ expression has not been evaluated in the colon relative to dietary change. In plasma, however, lipoprotein PLA 2 levels were decreased with a low-calorie diet but were unaffected by supplementation with n-3 fatty acids. ${ }^{125,126}$ In baboons, lipoprotein $\mathrm{PLA}_{2}$ activity was increased by a high-fat diet, but there was a significant interaction by genotype. ${ }^{127}$

\section{Cyclooxygenases and lipoxygenases}

Role in fatty acid metabolism. Many eicosanoids are formed from the COX-mediated and lipoxygenase (LOX)-mediated metabolism of the 20-carbon fatty acids that are released from phospholipids by $\mathrm{PLA}_{2}$. Eicosanoids, in turn, mediate many important biological functions. The prostanoids produced from COX tend to be best known for their involvement in reproduction and inflammation. Thromboxanes are also derived from COX and stimulate platelet aggregation, balancing the effects of prostanoids. Leukotrienes and hydroxyeicosatetraenoic acids (HETEs) produced from LOX-mediated metabolism of arachidonic acid have important roles in vascular tone, renal function, and pulmonary function, e.g., allergic reactions.

Role in colon cancer risk. PGE2 is the eicosanoid that has been the most widely studied with regard to colon cancer risk. PGE2 is formed by constitutive COX-1 and inducible COX-2 in the colonic mucosa, and it plays an important role in the expansion of cell populations in the colonic crypt and subsequent adenoma formation..$^{35-39}$ COX inhibitors conversely block proliferation, induce apoptosis, and inhibit angiogenesis in the colon..$^{40}$ Inhibition of both COX-1 and COX-2 appears effective for preventing polyp formation. ${ }^{41}$ Reducing the level of PGE2 in normal tissue, therefore, could lead to a reduced risk of polyp formation, and PGE2 levels have been indicated to be an appropriate candidate for a prevention endpoint. ${ }^{43}$ Inter- 


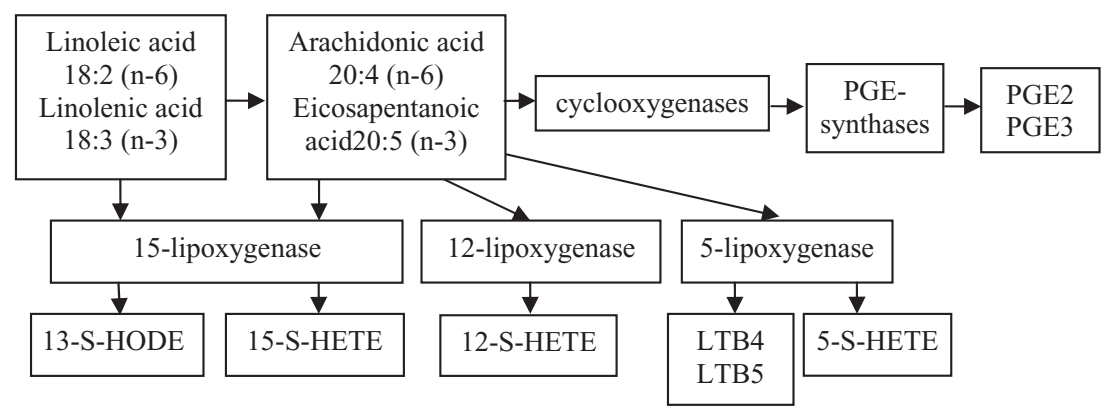

Figure 2 Formation of eicosanoids: select products. The other products shown are from n- 6 fatty acids except for PGE3 and LTB5, which are formed from n-3 fatty acids. Eicosapentaenoic acid inhibits oxygenation of arachidonic acid by cyclooxygenase 1 (COX-1), but this inhibition is modest with COX-2. ${ }^{197}$ The $n-9$ fatty acid oleic acid (18:1, n-9) forms 20:3 (n-9), which has not been studied as extensively (not shown), but it has been reported to form the unstable LTA3 via 5-lipoxygenase that, in turn, inhibits formation of LTB4. . $^{198,199}$

estingly, when EPA $(20: 5, n-3)$ is utilized as the substrate by COX, PGE3 is produced, which has lower proinflammatory action. ${ }^{128}$ Suppression of PPAR delta and PGE2 with elevation of PGE3 has been suggested to be the mechanism by which fish oil and pectin enhance colonocyte apoptosis. ${ }^{129}$

The literature strongly points towards an important role of COX and its metabolites in colon cancer, but the eicosanoid metabolic system is intricately linked and, presumably, regulated as a whole system. The products of 5-LOX and 12-LOX have been implicated in carcinogenesis, while the products of 15-LOX have not. The main products of 5-LOX and 12-LOX that have been studied are leukotriene B4 (LTB4) from 5-LOX and 12-HETE from 12-LOX. Levels of PGE2, LTB4, and 12-HETE were higher in inflamed versus normal mouse mucosa, while 15-HETE, from 15-LOX, was not increased and inhibited inflammation. ${ }^{130}$ The two 15-LOX products, 13-S-HODE and 15-HETE, induce apoptosis of colon cancer cells in vitro and can reflect enhanced differentiation of the cells. ${ }^{131,132}$ Accordingly, levels of 15 -HETE in serum were lower in colon cancer patients versus controls, and aspirin increased 15-HETE formation. ${ }^{131,133}$ In rats, 12-HETE appears to be involved in stimulating the proliferation of colonic epithelial cells. ${ }^{134}$ In Min mice, data indicates a shift from COX-mediated to 12-LOXmediated metabolism of arachidonic acid in polyps. ${ }^{135}$ LTB4 stimulated the proliferation of HT-29 and HCT-15 colon cancer cells in vitro, but leukotriene B5 (LTB5), an isomer of LTB4 derived from metabolism of EPA by 5-LOX, did not. ${ }^{136}$ The available data thus identify the COX and LOX enzymes that can be targeted as pro- or anti-carcinogenic.

Effect of diet. Many studies have examined the impact of dietary changes on eicosanoid production. Dietary corn oil and other n-6 fatty acids increased PGE2 levels and colon tumorigenesis, while n-3 and n-9 fatty acids (from fish and olive oil, respectively) have the opposite effect. ${ }^{46-48,50}$ Most studies found that increased intake of n-3 fatty acids resulted in decreased formation of LTB4, including that in rat colonic mucosa, and increased synthesis of 5-series leukotrienes, as shown in Figure $2 .^{47,137-141}$ Similarly, dietary eicosatrienoic acid (20:3, n-9) decreased LTB4 synthesis in rat peritoneal cells, and this effect was maximal when n- 6 fatty acid intake was low. ${ }^{142}$

Other aspects of the Mediterranean diet, namely the increased consumption of fruit, vegetables, and olive oil, could affect eicosanoid pathways as well. Phytochemicals, which have antioxidant properties, are plentiful in plant foods and would be expected to affect eicosanoids, since oxidative stress induces expression of COX-2. ${ }^{143}$ Olive oil contains many phenolic compounds with antioxidant and anti-inflammatory properties as well as oleic acid (18:1, n-9), which suppresses COX-2 via its effects on HER-2/neu receptors. ${ }^{144-152}$ Phenolic compounds in olive oil also were shown to inhibit leukocyte 5-LOX expression, ${ }^{153}$ and hydroxytyrosol, also found in olive oil, inhibited formation of LTB4. ${ }^{154}$ Plasma levels of LTB4 were decreased in humans consuming extra-virgin olive oil..$^{155}$ Olive oil decreased COX-2 protein levels in colon tissue of mice with colitis. ${ }^{156}$ Oleocanthal from olive oil was shown to inhibit the expression of both COX-1 and COX-2. ${ }^{157}$ Thus, a Mediterranean diet would be expected to decrease COX-1, 5-LOX, and 12-LOX expression and to increase 15-LOX expression in normal mucosa.

\section{Prostaglandin E synthase}

Role in colon cancer risk. Although prostaglandin E synthase (PGES) does not metabolize fatty acids directly, it is important to examine it in the context of colon carcinogenesis because of its role in the synthesis of PGE2 from the PGH2 produced by COX. ${ }^{158,159}$ Cytosolic PGES (cPGES) is constitutively expressed and complexes with 
COX-1. There are two other forms of PGES: microsomal PGES-1 (mPGES), which is induced by proinflammatory stimuli, and membrane-associated PGES-2, which is constitutively expressed and co-localizes with both COX-2 and COX-1. ${ }^{158,160}$ Deletion of mPGES-1 suppressed intestinal carcinogenesis greatly in one Min mouse model but not in another. ${ }^{161,162}$ mPGES-1 was shown to be induced in human inflammatory bowel disease and was overexpressed in 15 of 18 human colorectal cancer samples. ${ }^{163,164}$

Effect of diet. There are no studies yet available on the effects of dietary fatty acids on PGES levels or activity in the colon. Resveratrol, a compound found in red grapes, attenuated chemically induced colonic inflammation in mice and decreased levels of both PGES-1 and COX-2 proteins. ${ }^{165}$ In humans, a polymorphism in PGES was important for modulating the effects of fish intake on the risk of colorectal adenoma. ${ }^{166}$

\section{EFFECTS OF HIGH-MUFA DIETS ON LEVELS OF FATTY ACIDS IN BLOOD}

A number of studies have examined the effects of a diet high in MUFAs on levels of fatty acids in blood (Table 1). These studies have indicated that changes in the levels of fatty acids in blood, especially in the levels of PUFAs, are considerably smaller than the changes in dietary fatty acids. Significant beneficial health effects on insulin sensitivity can nevertheless be achieved, especially if saturated fat or total fat is not too high. ${ }^{71,167,168}$ Cardiovascular health was the focus of the Lyon Heart Study, and in that study a modified Mediterranean diet supplemented with a high-MUFA spread resulted in changes in fatty acids that were typically in the range of $10-15 \%$ (percent difference intervention versus control). This dietary change was sufficient to result in a relative risk of 0.28 for cardiac deaths and a relative risk of 0.39 for cancer deaths relative to the group receiving the American Heart Association Step I diet. ${ }^{169}$ Several other interventions with the Mediterranean diet have also resulted in significant benefits with regard to markers of cardiovascular risks, insulin resistance, and incidence of type II diabetes. ${ }^{170-172}$ In fact, many domains of human health have been shown to be affected by Mediterranean diets. ${ }^{3}$ This indicates that metabolic pathways limit the impact of diet on fatty acids in blood but that small changes in the levels of fatty acids in blood may be important for health outcomes.

Table 1 shows changes in the levels of fatty acids in blood in several studies that successfully increased MUFA intakes. In a fairly comprehensive exchange-list Mediterranean intervention performed in healthy women, changes in the levels of fatty acids in blood are among the higher increases reported in the literature for self-selected diets (Table 1). ${ }^{173,174}$ In that study, the correlation between the change in dietary MUFA intake and MUFA levels in plasma (from baseline to 6 months) was modest but significant ( $r=0.42, P=0.001$, Spearman). Correlations of changes in dietary saturated fatty acids and PUFAs, with their respective blood measures, were much lower, with $r<0.1$ in each case. In the study of Paniagua et al., ${ }^{167}$ in which all food was provided to study participants, changes in the levels of fatty acids in blood were similarly large. Despite the smaller changes observed in the KANWU, Medi-RIVAGE, and PREDIMED studies, significant health benefits were found for diabetes and markers of cardiovascular disease risk and insulin sensitivity. ${ }^{168,172,175}$

\section{EFFECTS OF HIGH-MUFA DIETS ON LEVELS OF FATTY ACIDS LEVELS IN THE COLON}

The relationship between dietary fatty acids and fatty acids in plasma and tissues is fairly well established, with changes in plasma occurring more rapidly than in tissues. ${ }^{176}$ The increase in 18:1 in adipose biopsies with a high-MUFA weight-loss diet was $4 \%$ over 6 months, which was significant but very small in magnitude. ${ }^{177}$ There are, however, examples of large changes in tissues. For example, 6 weeks of a high-PUFA diet resulted in a $36 \%$ increase in the level of linoleic acid in cheek cells. ${ }^{178}$ Changes in fatty acids in breast adipose tissue biopsies were much greater than in gluteal adipose tissues of women supplemented with $10 \mathrm{~g}$ of fish oil per day for 3 months. ${ }^{179}$

Much less data is available on fatty acids in the colon. In persons with ulcerative colitis, $18 \mathrm{~g} /$ day olive oil supplementation over 12 weeks significantly decreased 18:0 and 22:6 (30-40\%) and significantly increased 18:1 (n-9) by $38 \%$ in mucosa. Arachidonic acid (20:4,n-6) was decreased by $40 \%$, but this was not statistically significant. ${ }^{180}$ Arachidonic acid has been shown to be increased in inflammatory conditions of the colon. ${ }^{181,182}$ Arachidonic acid was also increased in mucosa from persons with inflammatory bowel disease, while the ratio of oleic acid to saturated fatty acids was increased in comparison with normal controls. ${ }^{183}$

Other studies in colonic mucosa have investigated changes with disease progression from normal mucosa to adenoma and cancer. These studies showed that, generally, arachidonic acid increased (but 18:2 decreased, perhaps due to increased metabolism to arachidonic acid), n-3 fatty acids decreased, n-6:n-3 ratios increased, and MUFAs decreased in cancer and adenoma tissue versus normal tissue. ${ }^{181,182,184-186}$ This indicates the relevance of these fatty acid COX substrates to colon cancer risk. ${ }^{184-186}$ Fatty acid levels in the normal colonic mucosa, which served as the "control" for the aforementioned 
Table 2 Phospholipid fatty acids measured in normal human colonic mucosa from eight healthy subjects.

\begin{tabular}{lclc}
\hline Fatty acid & $\begin{array}{l}\text { Mean* (\% of } \\
\text { fatty acids) }\end{array}$ & $\begin{array}{l}\text { Standard } \\
\text { deviation }\end{array}$ & Range \\
\hline $20: 4, \mathrm{n}-6$ & 6.8 & 1.2 & $3.5-8.8$ \\
$20: 5, \mathrm{n}-3$ & 2.3 & 0.8 & $0.5-3.6$ \\
$18: 2, \mathrm{n}-6$ & 16.1 & 2.2 & $9.2-18.4$ \\
$18: 1, \mathrm{n}-9$ & 26.8 & 2.2 & $23.8-31.7$ \\
$18: 0$ & 14.8 & 2.8 & $8.3-22.2$ \\
$16: 0$ & 24.7 & 4.6 & $19-32.3$ \\
\hline
\end{tabular}

${ }^{*}$ Adapted from Nishida et al. ${ }^{182}$ with permission from BMJ Publishing Group Ltd.

studies, are useful in estimating the expected variability in fatty acids between individuals. Typically, the coefficient of variation for arachidonic acid was about $15-20 \% .{ }^{182,184,185}$ One study published an observed range of fatty acid values, which was quite large in normal mucosa from eight healthy individuals (Table 2). The relationships between colonic fatty acid levels and colonic inflammation, however, remain to be determined.

\section{EFFECTS OF DIET ON THE COLONIC PROTEOME}

There is precedent for proteomic changes in the colon caused by diet or dietary compounds, and some of those same proteins are those involved in the carcinogenic phenotype. ${ }^{187,188}$ Diet has also been shown to affect proteins involved in inflammation. A soy intervention in women increased proteins with anti-inflammatory functions. ${ }^{189} \mathrm{~A}$ high-fat diet increased COX-2 protein by $45 \%$ in the rat colon. ${ }^{190}$ Even body weight can affect COX-2, and COX-2 mRNA in healthy colorectal mucosa was almost 2.6-fold higher in overweight and obese persons than in normalweight persons. ${ }^{191}$ Importantly, changes in proteins may be more valuable than changes in eicosanoids, which can be transiently formed in cells, ${ }^{192}$ indicating a need for future investigations of proteins affected by a Mediterranean diet. Proteomic studies are already under way in investigations of colon carcinogenesis. ${ }^{193-196}$ Targeted proteomics of the proteins expected to be affected by a Mediterranean diet should now be undertaken to develop a better understanding of the mechanisms that tie this diet to colon cancer risk.

\section{CONCLUSION}

In summary, the levels of proteins involved in uptake, trafficking, and metabolism of fatty acids can be expected to be altered by the Mediterranean diet. These proteins can contribute to interindividual variability in the levels of fatty acids and eicosanoids. A proteomic analysis of colonic mucosa would allow for a pathway-based approach of fatty acid metabolism. The relative levels of proteins may not be strictly predictive of enzymatic activity, but determining such levels would be an important step towards understanding how a Mediterranean diet can influence the risk of colon cancer. The identified proteins may then be good candidates for further study with regard to regulatory factors such as genetic polymorphisms and their subsequent impact on carcinogenesis. These kinds of approaches all have great potential for increasing understanding of how interindividual variability in colonic fatty acids affects inflammation and the risk of colon cancer.

\section{Acknowledgment}

Funding. Support was received from NIH grant 1RO1 CA120381 and NIH Cancer Center Support grant CA046592.

Declaration of interest. The author has no relevant interests to declare.

\section{REFERENCES}

1. World Cancer Research Fund/American Institute for Cancer Research. Food, Nutrition and Prevention of Cancer: A Global Perspective. Washington, DC: American Institute for Cancer Research; 1997.

2. Fung TT, Hu FB, Wu K, Chiuve SE, Fuchs CS, Giovannucci E. The Mediterranean and Dietary Approaches to Stop Hypertension (DASH) diets and colorectal cancer. Am J Clin Nutr. 2010;92:1429-1435.

3. Sofi F, Abbate R, Gensini GF, Casini A. Accruing evidence on benefits of adherence to the Mediterranean diet on health: an updated systematic review and meta-analysis. Am J Clin Nutr. 2010;92:1189-1196.

4. Gallus S, Bosetti C, La Vecchia C. Mediterranean diet and cancer risk. Eur J Cancer Prev. 2004;13:447-452.

5. English DR, Maclnnis RJ, Hodge AM, Hopper JL, Haydon AM, Giles GG. Red meat, chicken, and fish consumption and risk of colorectal cancer. Cancer Epidemiol Biomarkers Prev. 2004;13:1509-1514.

6. La Vecchia C. Mediterranean diet and cancer. Public Health Nutr. 2004;7:965-968.

7. Kojima M, Wakai K, Tokudome S, et al. Serum levels of polyunsaturated fatty acids and risk of colorectal cancer: a prospective study. Am J Epidemiol. 2005;161:462-471.

8. Cottet V, Bonithon-Kopp C, Kronborg O, et al. Dietary patterns and the risk of colorectal adenoma recurrence in a European intervention trial. Eur J Cancer Prev. 2005;14:2129.

9. Kesse E, Clavel-Chapelon F, Boutron-Ruault MC. Dietary patterns and risk of colorectal tumors: a cohort of French women of the National Education System (E3N). Am J Epidemiol. 2006;164:1085-1093.

10. Verberne L, Bach-Faig A, Buckland G, Serra-Majem L. Association between the Mediterranean diet and cancer risk: a review of observational studies. Nutr Cancer. 2010;62:860 870. 
11. Keys A. Seven Countries: A Multivariate Analysis of Death and Coronary Heart Disease. Cambridge, MA: Harvard University Press; 1980.

12. Panagiotakos D, Kalogeropoulos N, Pitsavos C, et al. Validation of the MedDietScore via the determination of plasma fatty acids. Int J Food Sci Nutr. 2009;60(Suppl 5):168180.

13. Trichopoulou A, Bamia C, Trichopoulos D. Anatomy of health effects of Mediterranean diet: Greek EPIC prospective cohort study. BMJ. 2009;338:b2337.

14. Beunza JJ, Toledo E, Hu FB, et al. Adherence to the Mediterranean diet, long-term weight change, and incident overweight or obesity: the Seguimiento Universidad de Navarra (SUN) cohort. Am J Clin Nutr. 2010;92:1484-1493.

15. Backlund MG, Mann JR, Dubois RN. Mechanisms for the prevention of gastrointestinal cancer: the role of prostaglandin E2. Oncology. 2005;69(Suppl 1):28-32.

16. American Cancer Society. Colorectal Cancer Facts and Figures - Special Edition 2005. Atlanta, GA: American Cancer Society; 2005.

17. Schottenfeld D, Fraumeni JF Jr. Cancer Epidemiology and Prevention, 2nd ed. New York: Oxford; 1996.

18. McMichael AJ, McCall MG, Hartshorne JM, Woodings TL. Patterns of gastro-intestinal cancer in European migrants to Australia: the role of dietary change. Int J Cancer. 1980;25:431-437.

19. Paspatis GA, Papanikolaou N, Zois E, Michalodimitrakis E. Prevalence of polyps and diverticulosis of the large bowel in the Cretan population. An autopsy study. Int J Colorectal Dis. 2001;16:257-261.

20. Simopoulos AP. The traditional diet of Greece and cancer. Eur J Cancer Prev. 2004;13:219-230.

21. Frenandez E, Vecchia CL, Gonzales JR, Lucchini F, Negri E, Levi F. Coverging patterns of colorectal cancer mortality in Europe. Eur J Cancer. 2005;41:430-437.

22. Mai V, Kant AK, Flood A, Lacey JV Jr, Schairer C, Schatzkin A. Diet quality and subsequent cancer incidence and mortality in a prospective cohort of women. Int J Epidemiol. 2005; 34:54-60.

23. Koushik A, Hunter DJ, Spiegelman D, et al. Fruits, vegetables, and colon cancer risk in a pooled analysis of 14 cohort studies. J Natl Cancer Inst. 2007;99:1471-1483.

24. Martinez-Gonzalez MA, Estruch R. Mediterranean diet, antioxidants and cancer: the need for randomized trials. Eur J Cancer Prev. 2004;13:327-335.

25. Kant AK, Schatzkin A, Graubard BI, Schairer C. A prospective study of diet quality and mortality in women. JAMA. 2000;283:2109-2115.

26. Gerber MJ, Scali JD, Michaud A, et al. Profiles of a healthful diet and its relationship to biomarkers in a population sample from Mediterranean southern France. J Am Diet Assoc. 2000;100:1164-1171.

27. Hoffmann I. Transcending reductionism in nutrition research. Am J Clin Nutr. 2003;78:S514-S516.

28. Trichopoulou A, Costacou T, Bamia C, Trichopoulos D. Adherence to a Mediterranean diet and survival in a Greek population. N Engl J Med. 2003;348:2599-2608.

29. Dixon LB, Subar AF, Peters U, et al. Adherence to the USDA Food Guide, DASH Eating Plan, and Mediterranean dietary pattern reduces risk of colorectal adenoma. J Nutr. 2007; 137:2443-2450.

30. Reedy J, Mitrou PN, Krebs-Smith SM, et al. Index-based dietary patterns and risk of colorectal cancer: the NIH-AARP Diet and Health Study. Am J Epidemiol. 2008;168:38-48.
31. Mitrou PN, Kipnis V, Thiebaut AC, et al. Mediterranean dietary pattern and prediction of all-cause mortality in a US population: results from the NIH-AARP Diet and Health Study. Arch Intern Med. 2007;167:2461-2468.

32. Peters U, Sinha R, Chatterjee N, et al. Dietary fibre and colorectal adenoma in a colorectal cancer early detection programme. Lancet. 2003;361:1491-1495.

33. Bingham SA, Day NE, Luben $R$, et al. Dietary fibre in food and protection against colorectal cancer in the European Prospective Investigation into Cancer and Nutrition (EPIC): an observational study. Lancet. 2003;361:1496-1501.

34. Alberts DS, Einspahr J, Ritenbaugh C, et al. The effect of wheat bran fiber and calcium supplementation on rectal mucosal proliferation rates in patients with resected adenomatous colorectal polyps. Cancer Epidemiol Biomarkers Prev. 1997;6:161-169.

35. Sonoshita M, Takaku K, Oshima M, Sugihara K-I, Taketo MM Cycloogenase-2 expression in fibroblasts and endothelial cells of intestinal polyps. Cancer Res. 2002;62:6846-6849.

36. Takeda $H$, Sonoshita $M$, Oshima $H$, et al. Cooperation of cyclooxygenase 1 and cyclooxygenase 2 in intestinal polyposis. Cancer Res. 2003;63:4872-4877.

37. Kargman SL, O'Neil GP, Vickers PJ, Evans JF, Mancini JA, Jothy S. Expression of prostaglandin $\mathrm{G} / \mathrm{H}$ synthase-1 and -2 protein in human colon cancer. Cancer Res. 1995;55:25562559.

38. Eberhart CE, Coffey RJ, Radhika A, Giardiello FM, Ferrenbach S, DuBois RN. Up-regulation of cyclooxygenase 2 gene expression in human colorectal adenomas and adenocarcinomas. Gastroenterology. 1994;107:1183-1188.

39. Sano $H$, Kawahito $Y$, Wilder RL. Expression of cyclooxygenase-1 and -2 in human colorectal cancer. Cancer Res. 1995;55:3785-3789.

40. Chan TA. Cyclooxygenase inhibition and mechanisms of colorectal cancer prevention. Curr Cancer Drug Targets. 2003;3:455-463.

41. Kitamura $T$, Itoh $M$, Noda $T$, Matsuura M, Wakabayashi $\mathrm{K}$. Combined effects of cyclooxygenase- 1 and cyclooxygenase-2 selective inhibitors on intestinal tumorigenesis in adenomatous polyposis coli gene knockout mice. Int J Cancer. 2004;109:576-580.

42. Rothwell PM, Wilson M, Elwin CE, et al. Long-term effect of aspirin on colorectal cancer incidence and mortality: 20-year follow-up of five randomised trials. Lancet. 2010; 376:1741-1750.

43. Sanderson P, Johnson IT, Mathers JC, et al. Emerging dietrelated surrogate end points for colorectal cancer: UK Food Standards Agency diet and colonic health workshop report. Br J Nutr. 2004;91:315-323.

44. Frommel TO, Dyavanapalli M, Oldham T, et al. Effect of aspirin on prostaglandin E2 and leukotriene B4 production in human colonic mucosa from cancer patients. Clin Cancer Res. 1997;3:209-213.

45. Smalley WE, DuBois RN. Colorectal cancer and nonsteroidal anti-inflammatory drugs. Adv Pharmacol. 1997;39:1-20.

46. Singh J, Hamid R, Reddy BS. Dietary fat and colon cancer: modulation of cyclooxygenase-2 by types and amount of dietary fat during the postinitiation stage of colon carcinogenesis. Cancer Res. 1997;57:3465-3470.

47. Broughton KS, Wade JW. Total fat and (n-3):(n-6) fat ratios influence eicosanoid production in mice. J Nutr. 2002;132: 88-94.

48. Mooney MA, Vaughn DM, Reinhart GA, et al. Evaluation of the effects of omega- 3 fatty acid-containing diets on the 
inflammatory stage of wound healing in dogs. Am J Vet Res. 1998;59:859-863.

49. Boudreau MD, Chanmugam PS, Hart SB, Lee SH, Hwang DH. Lack of dose response by dietary n-3 fatty acids at a constant ratio of $n-3$ to $n-6$ fatty acids in suppressing eicosanoid biosynthesis from arachidonic acid. Am J Clin Nutr. 1991; 54:111-117.

50. Bartoli R, Fernandez-Banares F, Navarro E, et al. Effect of olive oil on early and late events of colon carcinogenesis in rats: modulation of arachidonic acid metabolism and local prostaglandin $E(2)$ synthesis. Gut. 2000;46:191-199.

51. Schroeder F, Petrescu AD, Huang $H$, et al. Role of fatty acid binding proteins and long chain fatty acids in modulating nuclear receptors and gene transcription. Lipids. 2008;43:117.

52. Richieri GV, Ogata RT, Zimmerman AW, Veerkamp JH, Kleinfeld AM. Fatty acid binding proteins from different tissues show distinct patterns of fatty acid interactions. Biochemistry. 2000;39:7197-7204.

53. Furuhashi M, Hotamisligil GS. Fatty acid-binding proteins: role in metabolic diseases and potential as drug targets. Nat Rev Drug Discov. 2008;7:489-503.

54. Pelsers MM, Namiot Z, Kisielewski W, et al. Intestinal-type and liver-type fatty acid-binding protein in the intestine. Tissue distribution and clinical utility. Clin Biochem. 2003;36:529-535.

55. Levy E, Menard D, Delvin E, et al. Localization, function and regulation of the two intestinal fatty acid-binding protein types. Histochem Cell Biol. 2009;132:351-367.

56. Lenaerts K, Bouwman FG, Lamers WH, Renes J, Mariman EC. Comparative proteomic analysis of cell lines and scrapings of the human intestinal epithelium. BMC Genomics. 2007; 8:91.

57. Sweetser DA, Birkenmeier EH, Klisak IJ, et al. The human and rodent intestinal fatty acid binding protein genes. A comparative analysis of their structure, expression, and linkage relationships. J Biol Chem. 1987;262:16060-16071.

58. Thumser AE, Storch J. Liver and intestinal fatty acid-binding proteins obtain fatty acids from phospholipid membranes by different mechanisms. J Lipid Res. 2000;41:647656.

59. Zimmerman AW, Veerkamp JH. New insights into the structure and function of fatty acid-binding proteins. Cell Mol Life Sci. 2002;59:1096-1116.

60. Yamazaki T, Kanda T, Sakai Y, Hatakeyama K. Liver fatty acidbinding protein is a new prognostic factor for hepatic resection of colorectal cancer metastases. J Surg Oncol. 1999:72:83-87.

61. Adachi M, Kurotani R, Morimura K, et al. Peroxisome proliferator activated receptor gamma in colonic epithelial cells protects against experimental inflammatory bowel disease. Gut. 2006;55:1104-1113.

62. Coe NR, Bernlohr DA. Physiological properties and functions of intracellular fatty acid-binding proteins. Biochim Biophys Acta. 1998;1391:287-306.

63. Zimmer JS, Dyckes DF, Bernlohr DA, Murphy RC. Fatty acid binding proteins stabilize leukotriene A4: competition with arachidonic acid but not other lipoxygenase products. J Lipid Res. 2004;45:2138-2144.

64. Makowski L, Hotamisligil GS. Fatty acid binding proteins the evolutionary crossroads of inflammatory and metabolic responses. J Nutr. 2004;134:S2464-S2468.

65. Shen J, Pavone A, Mikulec C, et al. Protein expression profiles in the epidermis of cyclooxygenase-2 transgenic mice by 2-dimensional gel electrophoresis and mass spectrometry. J Proteome Res. 2007;6:273-286.

66. Chapkin RS, Clark AE, Davidson LA, Schroeder F, Zoran DL, Lupton JR. Dietary fiber differentially alters cellular fatty acid-binding protein expression in exfoliated colonocytes during tumor development. Nutr Cancer. 1998;32:107112.

67. Xiao R, Badger TM, Simmen FA. Dietary exposure to soy or whey proteins alters colonic global gene expression profiles during rat colon tumorigenesis. Mol Cancer. 2005;4:1.

68. Poirier $\mathrm{H}$, Niot I, Degrace $\mathrm{P}$, Monnot MC, Bernard A, Besnard P. Fatty acid regulation of fatty acid-binding protein expression in the small intestine. Am J Physiol. 1997:273:G289-G295.

69. Clarke SD, Armstrong MK. Cellular lipid binding proteins: expression, function, and nutritional regulation. FASEB J. 1989:3:2480-2487.

70. Alpers DH, Bass NM, Engle MJ, DeSchryver-Kecskemeti K. Intestinal fatty acid binding protein may favor differential apical fatty acid binding in the intestine. Biochim Biophys Acta. 2000;1483:352-362.

71. Marin C, Perez-Jimenez F, Gomez P, et al. The Ala54Thr polymorphism of the fatty acid-binding protein 2 gene is associated with a change in insulin sensitivity after a change in the type of dietary fat. Am J Clin Nutr. 2005;82:196-200.

72. Morcillo S, Rojo-Martinez G, Cardona F, et al. Effect of the interaction between the fatty acid binding protein 2 gene Ala54Thr polymorphism and dietary fatty acids on peripheral insulin sensitivity: a cross-sectional study. Am J Clin Nutr. 2007;86:1232-1237.

73. Okada T, Sato NF, Kuromori $Y$, et al. Thr-encoding allele homozygosity at codon 54 of FABP 2 gene may be associated with impaired delta 6 desaturase activity and reduced plasma arachidonic acid in obese children. J Atheroscler Thromb. 2006;13:192-196.

74. Goodridge AG. Regulation of the gene for fatty acid synthase. Fed Proc. 1986;45:2399-2405.

75. Rashid A, Pizer ES, Moga M, et al. Elevated expression of fatty acid synthase and fatty acid synthetic activity in colorectal neoplasia. Am J Pathol. 1997;150:201-208.

76. Hashimoto T, Kusakabe T, Watanabe K, et al. Liver-type fatty acid-binding protein is highly expressed in intestinal metaplasia and in a subset of carcinomas of the stomach without association with the fatty acid synthase status in the carcinoma. Pathobiology. 2004;71:115-122.

77. Ogino S, Nosho K, Meyerhardt JA, et al. Cohort study of fatty acid synthase expression and patient survival in colon cancer. J Clin Oncol. 2008;26:5713-5720.

78. Menendez JA, Vazquez-Martin A, Ortega FJ, Fernandez-Real JM. Fatty acid synthase: association with insulin resistance, type 2 diabetes, and cancer. Clin Chem. 2009:55:425-438.

79. Menendez JA, Lupu R. Fatty acid synthase and the lipogenic phenotype in cancer pathogenesis. Nat Rev Cancer. 2007; 7:763-777.

80. Pan $\mathrm{MH}$, Lin CC, Lin JK, Chen WJ. Tea polyphenol (-)epigallocatechin 3-gallate suppresses heregulin-beta1induced fatty acid synthase expression in human breast cancer cells by inhibiting phosphatidylinositol 3-kinase/Akt and mitogen-activated protein kinase cascade signaling. J Agric Food Chem. 2007;55:5030-5037.

81. Xiao R, Su Y, Simmen RC, Simmen FA. Dietary soy protein inhibits DNA damage and cell survival of colon epithelial cells through attenuated expression of fatty acid synthase. 
Am J Physiol Gastrointest Liver Physiol. 2008;294:G868G876.

82. Zhao WH, Gao C, Zhang YX, Tian WX. Evaluation of the inhibitory activities of aceraceous plants on fatty acid synthase. J Enzyme Inhib Med Chem. 2007;22:501-510.

83. Menendez JA, Lupu R. Mediterranean dietary traditions for the molecular treatment of human cancer: anti-oncogenic actions of the main olive oil's monounsaturated fatty acid oleic acid (18:1n-9). Curr Pharm Biotechnol. 2006;7:495502.

84. Dias VC, Parsons HG. Modulation in delta 9, delta 6, and delta 5 fatty acid desaturase activity in the human intestinal CaCo-2 cell line. J Lipid Res. 1995;36:552-563.

85. Menendez JA, Ropero S, Mehmi I, Atlas E, Colomer R, Lupu R. Overexpression and hyperactivity of breast cancerassociated fatty acid synthase (oncogenic antigen-519) is insensitive to normal arachidonic fatty acid-induced suppression in lipogenic tissues but it is selectively inhibited by tumoricidal alpha-linolenic and gamma-linolenic fatty acids: a novel mechanism by which dietary fat can alter mammary tumorigenesis. Int J Oncol. 2004;24:13691383.

86. Natali F, Siculella L, Salvati S, Gnoni GV. Oleic acid is a potent inhibitor of fatty acid and cholesterol synthesis in C6 glioma cells. J Lipid Res. 2007;48:1966-1975.

87. Kearney KE, Pretlow TG, Pretlow TP. Increased expression of fatty acid synthase in human aberrant crypt foci: possible target for colorectal cancer prevention. Int J Cancer. 2009;125:249-252.

88. Algire C, Amrein L, Zakikhani M, Panasci L, Pollak M. Metformin blocks the stimulative effect of a high-energy diet on colon carcinoma growth in vivo and is associated with reduced expression of fatty acid synthase. Endocr Relat Cancer. 2010;17:351-360.

89. Clarke SD. Polyunsaturated fatty acid regulation of gene transcription: a molecular mechanism to improve the metabolic syndrome. J Nutr. 2001;131:1129-1132.

90. U.S. Department of Agriculture, Agricultural Research Service. Nutrient intakes from food: mean amounts consumed per individual, by gender and age. In: What We Eat in America. 2010; NHANES 2007-2008. Available at: www.ars.usda.gov/ba/bhnre/fsrg.

91. Raatz SK, Bibus D, Thomas W, Kris-Etherton P. Total fat intake modifies plasma fatty acid composition in humans. J Nutr. 2001;131:231-234.

92. Rose DP, Connolly JM. Omega-3 fatty acids as cancer chemopreventive agents. Pharmacol Ther. 1999;83:217244.

93. Green CD, Ozguden-Akkoc CG, Wang Y, Jump DB, Olson LK. Role of fatty acid elongases in determination of de novo synthesized monounsaturated fatty acid species. J Lipid Res. 2010;51:1871-1877.

94. Guillou H, Zadravec D, Martin PG, Jacobsson A. The key roles of elongases and desaturases in mammalian fatty acid metabolism: insights from transgenic mice. Prog Lipid Res. 2010;49:186-199.

95. Tikhonenko M, Lydic TA, Wang Y, et al. Remodeling of retinal fatty acids in an animal model of diabetes: a decrease in long-chain polyunsaturated fatty acids is associated with a decrease in fatty acid elongases Elovl2 and Elovl4. Diabetes. 2010;59:219-227.

96. Hansen-Petrik MB, McEntee MF, Johnson BT, et al. Selective inhibition of delta- 6 desaturase impedes intestinal tumorigenesis. Cancer Lett. 2002;175:157-163.
97. Accioly MT, Pacheco P, Maya-Monteiro CM, et al. Lipid bodies are reservoirs of cyclooxygenase- 2 and sites of prostaglandin-E2 synthesis in colon cancer cells. Cancer Res. 2008;68:1732-1740.

98. Mangravite LM, Dawson K, Davis RR, Gregg JP, Krauss RM. Fatty acid desaturase regulation in adipose tissue by dietary composition is independent of weight loss and is correlated with the plasma triacylglycerol response. Am J Clin Nutr. 2007;86:759-767.

99. Pan DA, Hulbert AJ, Storlien LH. Dietary fats, membrane phospholipids and obesity. J Nutr. 1994;124:1555-1565.

100. Lands WE, Libelt B, Morris A, et al. Maintenance of lower proportions of $(n-6)$ eicosanoid precursors in phospholipids of human plasma in response to added dietary $(n-3)$ fatty acids. Biochim Biophys Acta. 1992;1180:147-162.

101. Tu WC, Cook-Johnson RJ, James MJ, Muhlhausler BS, Gibson RA. Omega-3 long chain fatty acid synthesis is regulated more by substrate levels than gene expression. Prostaglandins Leukot Essent Fatty Acids. 2010;83:61-68.

102. Ouyang $P$, Jiang $Y$, Doan HM, et al. Weight loss via exercise with controlled dietary intake may affect phospholipid profile for cancer prevention in murine skin tissues. Cancer Prev Res (Phila). 2010;3:466-477.

103. Wang Y, Botolin D, Christian B, Busik J, Xu J, Jump DB. Tissuespecific, nutritional, and developmental regulation of rat fatty acid elongases. J Lipid Res. 2005;46:706-715.

104. Shimamura K, Nagumo A, Miyamoto Y, et al. Discovery and characterization of a novel potent, selective and orally active inhibitor for mammalian ELOVL6. Eur J Pharmacol. 2010;630:34-41.

105. Triggiani $M$, Oriente $A$, Marone G. Differential roles for triglyceride and phospholipid pools of arachidonic acid in human lung macrophages. J Immunol. 1994;152:13941403.

106. Yu W, Bozza PT, Tzizik DM, et al. Co-compartmentalization of MAP kinases and cytosolic phospholipase A2 at cytoplasmic arachidonate-rich lipid bodies. Am J Pathol. 1998;152: 759-769.

107. Murakami M, Kambe T, Shimbara S, Kudo I. Functional coupling between various phospholipase A2s and cyclooxygenases in immediate and delayed prostanoid biosynthetic pathways. J Biol Chem. 1999;274:3103-3115.

108. Smith WL, DeWitt DL, Garavito RM. Cyclooxygenases: structural, cellular, and molecular biology. Annu Rev Biochem. 2000;69:145-182.

109. Osterstrom A, Dimberg J, Fransen K, Soderkvist P. Expression of cytosolic and group $X$ secretory phospholipase $A(2)$ genes in human colorectal adenocarcinomas. Cancer Lett. 2002;182:175-182.

110. Brock TG, Peters-Golden M. Activation and regulation of cellular eicosanoid biosynthesis. Sci World J. 2007;7:12731284.

111. Dennis EA. Phospholipase A2 in eicosanoid generation. Am J Respir Crit Care Med. 2000;161:S32-S35.

112. Pruzanski W, Vadas P, Browning J. Secretory non-pancreatic group II phospholipase A2: role in physiologic and inflammatory processes. J Lipid Mediat. 1993;8:161-167.

113. Fijneman RJ, Cormier RT. The roles of sPLA2-IIA (Pla2g2a) in cancer of the small and large intestine. Front Biosci. 2008;13:4144-4174.

114. Kennedy BP, Soravia C, Moffat J, et al. Overexpression of the nonpancreatic secretory group II PLA2 messenger RNA and protein in colorectal adenomas from familial adenomatous polyposis patients. Cancer Res. 1998;58:500-503. 
115. Wendum D, Svrcek M, Rigau V, et al. COX-2, inflammatory secreted PLA2, and cytoplasmic PLA2 protein expression in small bowel adenocarcinomas compared with colorectal adenocarcinomas. Mod Pathol. 2003;16:130-136.

116. Lagorce-Pages C, Paraf F, Wendum D, Martin A, Flejou JF. Expression of inflammatory secretory phospholipase A2 and cytosolic phospholipase A2 in premalignant and malignant Barrett's oesophagus. Virchows Arch. 2004;444:426435.

117. Dimberg J, Samuelsson A, Hugander A, Soderkvist P. Gene expression of cyclooxygenase-2, group II and cytosolic phospholipase A2 in human colorectal cancer. Anticancer Res. 1998;18:3283-3287.

118. Ilsley JN, Nakanishi M, Flynn C, et al. Cytoplasmic phospholipase $\mathrm{A} 2$ deletion enhances colon tumorigenesis. Cancer Res. 2005;65:2636-2643.

119. Minami T, Tojo H, Shinomura Y, Matsuzawa Y, Okamoto M. Increased group II phospholipase A2 in colonic mucosa of patients with Crohn's disease and ulcerative colitis. Gut. 1994;35:1593-1598.

120. Kuratko CN, Pence BC. Dietary lipid and iron modify normal colonic mucosa without affecting phospholipase A2 activity. Cancer Lett. 1995;95:181-187.

121. Rao CV, Simi B, Wynn TT, Garr K, Reddy BS. Modulating effect of amount and types of dietary fat on colonic mucosal phospholipase $A 2$, phosphatidylinositol-specific phospholipase $\mathrm{C}$ activities, and cyclooxygenase metabolite formation during different stages of colon tumor promotion in male F344 rats. Cancer Res. 1996;56:532537.

122. Hendrickse CW, Radley S, Donovan IA, Keighley MR, Neoptolemos JP. Activities of phospholipase A2 and diacylglycerol lipase are increased in human colorectal cancer. Br J Surg. 1995;82:475-478.

123. Tribler $\mathrm{L}$, Jensen $\mathrm{LT}$, Jorgensen $\mathrm{K}$, et al. Increased expression and activity of group IIA and X secretory phospholipase A2 in peritumoral versus central colon carcinoma tissue. Anticancer Res. 2007;27:3179-3185.

124. Praml C, Amler LC, Dihlmann S, Finke LH, Schlag P, Schwab M. Secretory type II phospholipase A2 (PLA2G2A) expression status in colorectal carcinoma derived cell lines and in normal colonic mucosa. Oncogene. 1998;17:2009_ 2012.

125. Tzotzas T, Filippatos TD, Triantos A, Bruckert E, Tselepis AD, Kiortsis DN. Effects of a low-calorie diet associated with weight loss on lipoprotein-associated phospholipase A2 (Lp-PLA2) activity in healthy obese women. Nutr Metab Cardiovasc Dis. 2008;18:477-482.

126. Pedersen MW, Koenig W, Christensen JH, Schmidt EB. The effect of marine $\mathrm{n}-3$ fatty acids in different doses on plasma concentrations of Lp-PLA2 in healthy adults. Eur J Nutr. 2009:48:1-5.

127. Vinson A, Mahaney MC, Diego VP, et al. Genotype-by-diet effects on co-variation in Lp-PLA2 activity and LDLcholesterol concentration in baboons fed an atherogenic diet. J Lipid Res. 2008;49:1295-1302.

128. Yang $P$, Chan D, Felix E, et al. Formation and antiproliferative effect of prostaglandin $\mathrm{E}(3)$ from eicosapentaenoic acid in human lung cancer cells. J Lipid Res. 2004;45:10301039.

129. Vanamala J, Glagolenko A, Yang P, et al. Dietary fish oil and pectin enhance colonocyte apoptosis in part through suppression of PPARdelta/PGE2 and elevation of PGE3. Carcinogenesis. 2008;29:790-796.
130. van Dijk AP, McCafferty DM, Wilson JH, Zijlstra FJ. 15-Hydroxy-eicosatetraenoic acid has minor antiinflammatory properties in colitis. Agents Actions. 1993;38(Suppl 2):C120-C121.

131. Chen GG, Xu H, Lee JF, et al. 15-hydroxy-eicosatetraenoic acid arrests growth of colorectal cancer cells via a peroxisome proliferator-activated receptor gamma-dependent pathway. Int J Cancer. 2003;107:837-843.

132. Shureiqi I, Wojno KJ, Poore JA, et al. Decreased 13-Shydroxyoctadecadienoic acid levels and 15-lipoxygenase-1 expression in human colon cancers. Carcinogenesis. 1999; 20:1985-1995.

133. Smith WL, Meade EA, DeWitt DL. Pharmacology of prostaglandin endoperoxide synthase isozymes-1 and -2. Ann N Y Acad Sci. 1994;714:136-142.

134. DeRubertis FR, Craven PA, Saito R. Bile salt stimulation of colonic epithelial proliferation. Evidence for involvement of lipoxygenase products. J Clin Invest. 1984;74:16141624.

135. Lepage MG, Wargovich M, Smith TJ. Arachidonic acid metabolism in the Min mouse interstine: colon tumor 12-lipoxygenase and effect of green tea polyphenols. Proc Am Assoc Cancer Res. 2005;46. Available at: http:// aacrmeetingabstracts.org/cgi/content/abstract/2005/1/ 177-a. Accessed 10 January 2011.

136. Bortuzzo C, Hanif R, Kashfi K, Staiano-Coico L, Shiff SJ, Rigas $B$. The effect of leukotrienes $B$ and selected HETEs on the proliferation of colon cancer cells. Biochim Biophys Acta. 1996;1300:240-246.

137. Shimizu T, Suzuki M, Lee T, Igarashi J, Kaneko K, Yamashiro Y. Effects of n-3 polyunsaturated fatty acids on indomethacininduced changes in eicosanoid production and blood flow in the gastric mucosa of rats. Prostaglandins Leukot Essent Fatty Acids. 2003;69:33-37.

138. Kurlandsky LE, Bennink MR, Webb PM, Ulrich PJ, Baer LJ. The absorption and effect of dietary supplementation with omega-3 fatty acids on serum leukotriene B4 in patients with cystic fibrosis. Pediatr Pulmonol. 1994;18:211217

139. Hall JA, Van Saun RJ, Wander RC. Dietary (n-3) fatty acids from menhaden fish oil alter plasma fatty acids and leukotriene B synthesis in healthy horses. J Vet Intern Med. 2004; 18:871-879.

140. Surette $M E$, Koumenis $I L$, Edens $M B$, et al. Inhibition of leukotriene biosynthesis by a novel dietary fatty acid formulation in patients with atopic asthma: a randomized, placebo-controlled, parallel-group, prospective trial. Clin Ther. 2003;25:972-979.

141. Begum R, Belury MA, Burgess JR, Peck LW. Supplementation with n-3 and n-6 polyunsaturated fatty acids: effects on lipoxygenase activity and clinical symptoms of pruritus in hemodialysis patients. J Ren Nutr. 2004;14:233-241.

142. Cleland LG, Gibson RA, Neumann MA, Hamazaki T, Akimoto K, James MJ. Dietary ( $n-9)$ eicosatrienoic acid from a cultured fungus inhibits leukotriene B4 synthesis in rats and the effect is modified by dietary linoleic acid. J Nutr. 1996;126:1534-1540.

143. Tanabe T, Tohnai N. Cyclooxygenase isozymes and their gene structures and expression. Prostaglandins Other Lipid Mediat. 2002;68-69:95-114.

144. Manna C, D'Angelo S, Migliardi V, et al. Protective effect of the phenolic fraction from virgin olive oils against oxidative stress in human cells. J Agric Food Chem. 2002;50:65216526. 
145. Braga C, La Vecchia C, Franceschi S, et al. Olive oil, other seasoning fats, and the risk of colorectal carcinoma. Cancer. 1998:82:448-453.

146. Palozza P, Serini S, Maggiano N, Tringali G, Navarra P, Ranelletti FO, Calviello G. $\beta$-Carotene downregulates the steady-state and heregulin-alpha-induced COX-2 pathways in colon cancer cells. J Nutr. 2005;135:129-136.

147. Manna C, Galletti P, Cucciolla V, Montedoro G, Zappia V. Olive oil hydroxytyrosol protects human erythrocytes against oxidative damages. J Nutr Biochem. 1999;10:159165.

148. Owen RW, Mier W, Giacosa A, Hull WE, Spiegelhalder B, Bartsch $\mathrm{H}$. Phenolic compounds and squalene in olive oils: the concentration and antioxidant potential of total phenols, simple phenols, secoiridoids, lignans and squalene. Food Chem Toxicol. 2000;38:647-659.

149. Visioli F, Galli C. Biological properties of olive oil phytochemicals. Crit Rev Food Sci Nutr. 2002;42:209-221.

150. Menendez JA, Vellon L, Lupu R. Targeting fatty acid synthase-driven lipid rafts: a novel strategy to overcome trastuzumab resistance in breast cancer cells. Med Hypotheses. 2005;64:997-1001.

151. Vadlamudi R, Mandal M, Adam L, Steinbach G, Mendelsohn J, Kumar R. Regulation of cyclooxygenase-2 pathway by HER2 receptor. Oncogene. 1999;18:305-314.

152. Half E, Broaddus R, Danenberg KD, Danenberg PV, Ayers GD, Sinicrope FA. HER-2 receptor expression, localization, and activation in colorectal cancer cell lines and human tumors. Int J Cancer. 2004;108:540-548.

153. de la Puerta R, Ruiz Gutierrez V, Hoult JR. Inhibition of leukocyte 5-lipoxygenase by phenolics from virgin olive oil. Biochem Pharmacol. 1999;57:445-449.

154. Petroni A, Blasevich M, Papini N, Salami M, Sala A, Galli C. Inhibition of leukocyte leukotriene B4 production by an olive oil-derived phenol identified by mass-spectrometry. Thromb Res. 1997;87:315-322.

155. Bogani P, Galli C, Villa M, Visioli F. Postprandial antiinflammatory and antioxidant effects of extra virgin olive oil. Atherosclerosis. 2007;190:181-186.

156. Hegazi RA, Saad RS, Mady $H$, Matarese LE, O'Keefe $S$, Kandil HM. Dietary fatty acids modulate chronic colitis, colitis-associated colon neoplasia and COX-2 expression in IL-10 knockout mice. Nutrition. 2006;22:275-282.

157. Beauchamp GK, Keast RS, Morel D, et al. Phytochemistry: ibuprofen-like activity in extra-virgin olive oil. Nature. 2005;437:45-46.

158. Murakami M, Kudo I. Prostaglandin E synthase: a novel drug target for inflammation and cancer. Curr Pharm Des. 2006;12:943-954.

159. Schade S, Bezugla Y, Kolada A, Kamionka S, Scheibe R, Dieter P. Diverse functional coupling of cyclooxygenase 1 and 2 with final prostanoid synthases in liver macrophages. Biochem Pharmacol. 2002;64:1227-1232.

160. St-Onge M, Flamand N, Biarc J, et al. Characterization of prostaglandin E2 generation through the cyclooxygenase (COX)-2 pathway in human neutrophils. Biochim Biophys Acta. 2007;1771:1235-1245.

161. Nakanishi M, Montrose DC, Clark P, et al. Genetic deletion of mPGES-1 suppresses intestinal tumorigenesis. Cancer Res. 2008;68:3251-3259.

162. Elander N, Ungerback J, Olsson H, Uematsu S, Akira S, Soderkvist P. Genetic deletion of mPGES-1 accelerates intestinal tumorigenesis in $\mathrm{APC}(\mathrm{Min} /+)$ mice. Biochem Biophys Res Commun. 2008;372:249-253. Epub 2008 May 15.
163. Subbaramaiah K, Yoshimatsu K, Scherl E, et al. Microsomal prostaglandin E synthase-1 is overexpressed in inflammatory bowel disease. Evidence for involvement of the transcription factor Egr-1. J Biol Chem. 2004;279:12647-12658.

164. Yoshimatsu K, Golijanin D, Paty PB, et al. Inducible microsomal prostaglandin $\mathrm{E}$ synthase is overexpressed in colorectal adenomas and cancer. Clin Cancer Res. 2001;7:3971-3976.

165. Sanchez-Fidalgo S, Cardeno A, Villegas I, Talero E, de la Lastra CA. Dietary supplementation of resveratrol attenuates chronic colonic inflammation in mice. Eur J Pharmacol. 2010;633:78-84.

166. Poole EM, Hsu L, Xiao L, et al. Genetic variation in prostaglandin E2 synthesis and signaling, prostaglandin dehydrogenase, and the risk of colorectal adenoma. Cancer Epidemiol Biomarkers Prev. 2010;19:547-557.

167. Paniagua JA, de la Sacristana AG, Sanchez E, et al. A MUFArich diet improves postprandial glucose, lipid and GLP-1 responses in insulin-resistant subjects. J Am Coll Nutr. 2007;26:434-444.

168. Vessby B, Uusitupa M, Hermansen $K$, et al. Substituting dietary saturated for monounsaturated fat impairs insulin sensitivity in healthy men and women: the KANWU Study. Diabetologia. 2001;44:312-319.

169. de Lorgeril M, Salen P, Martin JL, Monjaud I, Boucher P, Mamelle N. Mediterranean dietary pattern in a randomized trial: prolonged survival and possible reduced cancer rate. Arch Intern Med. 1998;158:1181-1187.

170. Lairon D. Intervention studies on Mediterranean diet and cardiovascular risk. Mol Nutr Food Res. 2007;51:1209-1214.

171. Estruch R, Martinez-Gonzalez MA, Corella D, et al. Effects of a Mediterranean-style diet on cardiovascular risk factors: a randomized trial. Ann Intern Med. 2006;145:1-11.

172. Salas-Salvado J, Bullo M, Babio N, et al. Reduction in the incidence of type 2 diabetes with the Mediterranean diet: results of the PREDIMED-Reus nutrition intervention randomized trial. Diabetes Care. 2010;34:14-19.

173. Djuric Z, Ren J, Blythe J, VanLoon G, Sen A. A Mediterranean dietary intervention in healthy American women changes plasma carotenoids and fatty acids in distinct clusters. Nutr Res. 2009;29:156-163.

174. Djuric Z, Vanloon G, Radakovich K, Dilaura NM, Heilbrun LK, Sen A. Design of a Mediterranean exchange list diet implemented by telephone counseling. J Am Diet Assoc. 2008; 108:2059-2065.

175. Vincent-Baudry S, Defoort C, Gerber M, et al. The MediRIVAGE study: reduction of cardiovascular disease risk factors after a 3-mo intervention with a Mediterranean-type diet or a low-fat diet. Am J Clin Nutr. 2005;82:964-971.

176. Field CJ, Angel A, Clandinin MT. Relationship of diet to the fatty acid composition of human adipose tissue structural and stored lipids. Am J Clin Nutr. 1985;42:1206-1220.

177. Due A, Larsen TM, Mu H, Hermansen K, Stender S, Astrup A. Comparison of 3 ad libitum diets for weight-loss maintenance, risk of cardiovascular disease, and diabetes: a 6-mo randomized, controlled trial. Am J Clin Nutr. 2008;88:12321241.

178. McMurchie EJ, Margetts BM, Beilin LJ, Croft KD, Vandongen R, Armstrong BK. Dietary-induced changes in the fatty acid composition of human cheek cell phospholipids: correlation with changes in the dietary polyunsaturated/saturated fat ratio. Am J Clin Nutr. 1984;39:975-980.

179. Bagga D, Capone S, Wang HJ, et al. Dietary modulation of omega-3/omega-6 polyunsaturated fatty acid ratios in 
patients with breast cancer. J Natl Cancer Inst. 1997; 89:1123-1131.

180. Hillier K, Jewell R, Dorrell L, Smith CL. Incorporation of fatty acids from fish oil and olive oil into colonic mucosal lipids and effects upon eicosanoid synthesis in inflammatory bowel disease. Gut. 1991;32:1151-1155.

181. Buhner S, Nagel E, Korber J, Vogelsang H, Linn T, Pichlmayr R. Ileal and colonic fatty acid profiles in patients with active Crohn's disease. Gut. 1994;35:1424-1428.

182. Nishida T, Miwa $H$, Shigematsu A, Yamamoto $M$, lida $M$, Fujishima M. Increased arachidonic acid composition of phospholipids in colonic mucosa from patients with active ulcerative colitis. Gut. 1987;28:1002-1007.

183. Pacheco S, Hillier K, Smith C. Increased arachidonic acid levels in phospholipids of human colonic mucosa in inflammatory bowel disease. Clin Sci (Lond). 1987;73:361-364.

184. Shim YJ, Choi KY, Lee WC, Kim MK, Lee SY, Lee-Kim YC Phospholipid fatty acid patterns in the mucosa of human colorectal adenomas and carcinomas. Nutr Res. 2005; 25:261-269.

185. Fernandez-Banares F, Esteve M, Navarro E, et al. Changes of the mucosal n3 and n6 fatty acid status occur early in the colorectal adenoma-carcinoma sequence. Gut. 1996;38: 254-259.

186. Szachowicz-Petelska B, Sulkowski S, Figaszewski ZA. Altered membrane free unsaturated fatty acid composition in human colorectal cancer tissue. Mol Cell Biochem. 2007; 294:237-242.

187. Drew JE, Padidar S, Horgan G, et al. Salicylate modulates oxidative stress in the rat colon: a proteomic approach. Biochem Pharmacol. 2006;72:204-216.

188. Murugan RS, Mohan KV, Uchida K, Hara Y, Prathiba D, Nagini S. Modulatory effects of black tea polyphenols on oxidant-antioxidant profile and expression of proliferation, apoptosis, and angiogenesis-associated proteins in the rat forestomach carcinogenesis model. J Gastroenterol. 2007:42:352-361.

189. Fuchs D, Vafeiadou K, Hall WL, et al. Proteomic biomarkers of peripheral blood mononuclear cells obtained from postmenopausal women undergoing an intervention with soy isoflavones. Am J Clin Nutr. 2007:86:1369-1375.

190. Delage B, Bairras C, Buaud B, Pallet V, Cassand P. A high-fat diet generates alterations in nuclear receptor expression: prevention by vitamin A and links with cyclooxygenase-2 and beta-catenin. Int J Cancer. 2005;116:839-846.
191. Delage B, Rullier A, Capdepont M, Rullier E, Cassand P. The effect of body weight on altered expression of nuclear receptors and cyclooxygenase- 2 in human colorectal cancers. Nutr J. 2007;6:20.

192. Tabibiazar R, Wagner RA, Deng A, Tsao PS, Quertermous T. Proteomic profiles of serum inflammatory markers accurately predict atherosclerosis in mice. Physiol Genomics. 2006;25:194-202.

193. Habermann JK, Paulsen U, Roblick UJ, et al. Stage-specific alterations of the genome, transcriptome, and proteome during colorectal carcinogenesis. Genes Chromosomes Cancer. 2007;46:10-26.

194. Rho JH, Qin S, Wang JY, Roehrl MH. Proteomic expression analysis of surgical human colorectal cancer tissues: up-regulation of PSB7, PRDX1, and SRP9 and hypoxic adaptation in cancer. J Proteome Res. 2008;7:2959-2972.

195. Hsieh SY, Shih TC, Yeh CY, Lin CJ, Chou YY, Lee YS. Comparative proteomic studies on the pathogenesis of human ulcerative colitis. Proteomics. 2006;6:5322-5331.

196. Alrawi SJ, Schiff M, Carroll RE, et al. Aberrant crypt foci. Anticancer Res. 2006;26:107-119.

197. Wada M, DeLong CJ, Hong YH, et al. Enzymes and receptors of prostaglandin pathways with arachidonic acid-derived versus eicosapentaenoic acid-derived substrates and products. J Biol Chem. 2007;282:22254-22266.

198. Evans JF, Nathaniel DJ, Zamboni RJ, Ford-Hutchinson AW. Leukotriene A3. A poor substrate but a potent inhibitor of rat and human neutrophil leukotriene A4 hydrolase. J Biol Chem. 1985;260:10966-10970.

199. James MJ, Gibson RA, Neumann MA, Cleland LG. Effect of dietary supplementation with n-9 eicosatrienoic acid on leukotriene B4 synthesis in rats: a novel approach to inhibition of eicosanoid synthesis. J Exp Med. 1993;178: 2261-2265.

200. Urquiaga I, Guasch V, Marshall G, et al. Effect of Mediterranean and Occidental diets, and red wine, on plasma fatty acids in humans. An intervention study. Biol Res. 2004; 37:253-261.

201. Zazpe I, Sanchez-Tainta A, Estruch R, et al. A large randomized individual and group intervention conducted by registered dietitians increased adherence to Mediterranean-type diets: the PREDIMED study. J Am Diet Assoc. 2008;108: 1134-1144; discussion 1145 